\author{
A. B. Нетудихатка \\ orcid.org/0000-0003-4947-7611 \\ аспірант кафедри поліцейського права \\ Національної академії внутрішніх справ
}

\title{
ОСОБЛИВОСТІ ПРОКУРОРСЬКОГО НАГЛЯДУ ЗА ДОТРИМАННЯМ ЗАКОННОСТІ ТА ДИСЦИПЛІНИ В ДІЯЛЬНОСТІ НАЦІОНАЛЬНОЇ ПОЛІЦІЇ УКРАЇНИ
}

Постановка проблеми. Правореалізаційна діяльність накладає на закріплені у нормах права бажані характеристики управлінських правовідносин відбиток особливостей реальних життєвих обставин, які не можливо було передбачити та прорахувати за допомогою нормативно-правового регулювання, суб'єктивного сприйняття учасниками правовідносин відповідних правил поведінки, а також власних обов'язків, прав та інтересів. Тому Національна поліція України, яка забезпечує охорону прав і свобод людини, підтримання публічної безпеки і порядку, потребує наявності системи стримувань і противаг, що запобігатиме зловживанню управлінською компетенцією, наданою поліцейським, узурпації державно-владних повноважень і порушенню прав і свобод людини. У наведеному контексті незамінну роль відіграє саме проведення зовнішнього нагляду за законністю та дисципліною в діяльності поліції, що здійснюється незалежним суб'єктом, наприклад, прокуратурою, адже такий орган володіє більш широкими повноваженнями, насамперед у процесуальній сфері, щодо запобігання вчиненню поліцейськими різних порушень закону - процедурних і технічних - і протидії заздалегідь спланованим та організованим обмеженням прав і свобод людини та громадянина. Звичайно, у наведеного нагляду є певні недоліки та переваги, з'ясування яких є важливою науково-теоретичною задачею.

Аналіз останніх досліджень і публікацій. Аналізуючи положення наукової доктрини, варто зауважити, що здебільшого вчені присвячували свої роботи розкриттю загальної проблематики сутності й особливостей здійснення прокурорського нагляду. Серед таких праць слід відзначити дослідження О.П. Бабікова, В.О. Глушкова, Ю.М. Грошевого, Е.О. Дідоренка, С.В. Єськова, В.С. Зеленецького, П.М. Каркача, І.М. Козякова, М.Й. Курочки, І.Є. Марочкіна, О.Р. Михайленка, С.М. Піскуна, М.А. Погорецького, Б.Г. Розовського, Г.П. Середи, В.О. Черкова, М.Є. Шумила.

Невирішені раніше проблеми. Сьогодні бракує системних досліджень із питання особливостей прокурорського нагляду саме за законністю та дисципліною в діяльності поліції.

Метою статті є з'ясування особливостей прокурорського нагляду за законністю та дисципліною в діяльності Національної поліції України.
Виклад основного матеріалу. Слід зауважити, що прокурорський нагляд останніми роками зазнав багато змін у зв'язку з реформуванням зазначеної сфери діяльності. Через це сьогодні за Конституцією України та Законом України «Про прокуратуру» від 14 жовтня 2014 р. № 1697-VII нагляд прокуратури поширюється на діяльність поліції виключно за такими напрямами: 1) дотримання законності у ході проведення оперативно-розшукової діяльності, дізнання, досудового слідства та 2) дотримання законності при застосуванні заходів примусового характеру, пов'язаних із обмеженням особистої свободи громадян. Тобто слід зауважити, що прокуратура не уповноважена реалізовувати наглядові функції щодо забезпечення дотримання службової дисципліни в діяльності Національної поліції України, об’єктом прокурорського нагляду за наведеними вище напрямами є виключно дотримання законності наведеними органами уїхнійпроцесуальнійдіяльності.

P.P. Трагнюк зауважує, що на сучасному етапі Національна поліція є основним об’єктом прокурорського нагляду, головним органом правопорядку, на якому зосереджено конституційну функцію прокуратури з організації та процесуального керівництва досудовим розслідуванням, вирішенням відповідно до закону інших питань під час кримінального провадження, нагляду за негласними та іншими слідчими і розшуковими діями органів правопорядку. Щодо Національної поліції прокуратура здійснює свої повноваження за такими напрямами, як: 1) організація і процесуальне керівництво досудовими розслідуваннями, що здійснюються слідчими Національної поліції; 2) нагляд за проведенням оперативними підрозділами поліції оперативно-розшукової діяльності; 3) координація діяльності Національної поліції у сфері запобігання злочинності з відповідною діяльністю інших органів правопорядку. Також на перехідний період прокуратура здійснює нагляд за застосуванням Національною поліцією примусових заходів, які обмежують особисту свободу громадян. Також автор зазначає, що під час здійснення нагляду за діяльністю Національної поліції прокурор передусім перевіряє відповідність закону дій і рішень поліцейських при здійсненні покладених на них повноважень [1, с. 108]. 
Висловлювання науковця про те, що діяльність саме органів поліції є основним об'єктом прокурорського нагляду, можна проілюструвати даними звіту про роботу прокурора за січень-березень $2020 \mathrm{p}$. За наведеним звітом, за зазначений період у ході здійснення нагляду за законністю проведення досудового розслідування було виявлено та внесено до Реєстру відомості про вчинене 2021 кримінальне правопорушення, з яких 2018 слідчими поліції. Кількість наданих письмових вказівок - 55889 , із яких 53299 - слідчим поліції. Кількість розглянутих прокурором клопотань слідчих - 19499 (погоджено) та 706 (відмовлено), із яких 16496 і 617 відповідно - клопотання слідчих поліції. Кількість перевірених прокуратурою оперативно-розшукових справ - 28691 , з яких 27328 - справи поліції. Кількість скасованих прокурором незаконних постанов - 488 , із яких $464-$ постанови поліції (з них 192 - про заведення ОРС, 270 - про закриття ОРС) [2].

Тобто дійсно варто відзначити, що діяльністю поліції охоплено найбільшу кількість справ, у яких проводяться оперативно-розшукова діяльність, дізнання та досудове слідство. Наведені обставини зумовлюють необхідність у зазначених органів здійснювати постійну, системну та тісну співпрацю. Для ефективної реалізації визначених чинним законодавством завдань із нагляду за законністю діяльності поліції прокуратурі необхідно розробляти та втілювати в життя комплексні організаційно-правові заходи, спрямовані на виконання таких завдань, а також налагодження процесуальної, організаційної та інформаційної взаємодії з поліцією.

Відповідно до норм Кримінального процесуального кодексу України від 13 квітня 2012 р. № 4651-VI визначено повноваження прокурора під час здійснення ним нагляду за додержанням законів під час проведення досудового розслідування у формі процесуального керівництва досудовим розслідуванням, серед яких, наприклад: мати повний доступ до матеріалів, документів та інших відомостей, що стосуються досудового розслідування; доручати органу досудового розслідування проведення досудового розслідування; доручати слідчому, органу досудового розслідування проведення у встановлений прокурором строк слідчих (розшукових) дій, негласних слідчих (розшукових) дій, інших процесуальних дій або давати вказівки щодо їх проведення чи брати участь у них, а в необхідних випадках - особисто проводити слідчі (розшукові) та процесуальні дії; скасовувати незаконні та необгрунтовані постанови слідчих; ініціювати перед керівником органу досудового розслідування питання про відсторонення слідчого від проведення досудового розслідування та призначення іншого слідчого за наявності підстав, передбачених цим Кодексом для його відводу, або у разі неефективного досудового розслідування; погоджувати або відмовляти у погодженні клопотань слідчого до слідчого судді про проведення слідчих (розшукових) дій, негласних слідчих (розшукових) дій, інших процесуальних дій у випадках, передбачених цим Кодексом, чи самостійно подавати слідчому судді такі клопотання; затверджувати чи відмовляти у затвердженні обвинувального акта, вносити зміни до складеного слідчим обвинувального акта чи зазначених клопотань, самостійно складати обвинувальний акт чи зазначені клопотання; здійснювати інші повноваження, передбачені цим Кодексом [3].

Тобто у зазначеному напрямі за прокуратурою закріплено широкі процесуальні повноваження щодо погодження різних актів органів поліції, клопотань про проведення слідчих і негласних розшукових дій тощо. Проте основною їх особливістю $є$ те, що усі повноваження прокурора під час здійснення нагляду за дотриманням законності у діяльності поліції лежать виключно у процесуальній у площині. У разі здійснення заходів нагляду прокуратури, надання відповідних вказівок (наприклад, у разі скасування незаконних і необгрунтованих постанов слідчих, ініціювання питання про відсторонення слідчого від проведення досудового розслідування та призначення іншого слідчого, в т. ч. у разі неефективного досудового розслідування) наслідком для поліцейських, котрі проводять досудове розслідування, дізнання, оперативно-розшукову діяльність, може бути і притягнення до дисциплінарної відповідальності. Це опосередкований наслідок, який уже залежить від конкретних обставин порушень законності та службової дисципліни, що спричинили винесення прокурором акта реагування та юридичної волі керівника.

Д.Ю. Фурсов, досліджуючи особливості прокурорського нагляду за додержанням законів під час досудового розслідування кримінальних правопорушень проти безпеки дорожнього руху, зазначав, що процесуальні керівники здебільшого не володіють методикою і тактикою розслідування зазначеної категорії кримінальних правопорушень, у зв'язку із чим надалі спонтанно проводять досудове розслідування, що доводить факт неналежного виконання своїх обов'язків і порушення вимог п. 1 ч. 3 p. IV «Порядку організації діяльності прокурорів і слідчих органів прокуратури», затвердженого наказом Генеральної прокуратури України № 51 від 28 березня 2019 р. Наприклад, прокурор не звертає належної уваги слідчого на дотримання вимог до проведення такої слідчої дії, як слідчий експеримент, у частині своєчасності проведення та відповідності погодних і дорожніх умов тим, які були під час дорожньо-транспортної пригоди (далі - ДТП) (сніг, дощ, наявність листя на деревах, туман тощо). Ще однією проблемною 
частиною прокурорського нагляду зазначеної сфери є неефективний контроль за якістю проведених процесуальних дій слідчим. Нерідко процесуальні керівники не звертають належної уваги на результати, отримані у процесі проведення слідчих дій, a саме на неповноту отриманих вихідних даних i порушення процедури складання протоколів слідчих дій. Вирішення зазначеної проблеми автор вбачає, як слушно зауважив А.А. Дворник, у постійному, щільному характері прокурорського нагляду [4, с. 89], у дотриманні керівником органу прокуратури принципу спеціалізації під час призначення процесуального керівника за справами зазначеної категорії правопорушень. Тому науковець наголошує, що процесуальним керівником у кримінальних провадженнях повинні бути прокурори, які володіють досвідом контрольно-наглядової діяльності в зазначеній сфері, мають чітке розуміння методики розслідування конкретного виду правопорушення та сконцентровані переважно на процесуальному керівництві кримінальних проваджень зазначеної категорії [5, с. 143].

Аналізуючи таку позицію, зауважимо, що дійсно у ході здійснення прокурорського нагляду за дотриманням законності у діяльності поліції сьогодні існує велика кількість недоліків. Аналізуючи судову практику, звертаємо увагу на кількість ухвал і постанов, прийнятих за розглядом скарги на дії як слідчого, так і прокурора як його процесуального керівника. Здебільшого підставою для оскарження законності ведення досудового слідства $€$ недотримання розумних строків у кримінальному провадженні. Прикладом можуть стати ухвали Коропського районного суду Чернігівської області від 25 березня 2020 р. у справі № 735/348/20 та Шевченківського районного суду м. Чернівці від 21 січня 2020 р. у справі № 727/237/20. Наприклад, за змістом останньої наведеної ухвали, скаржник звернувся до слідчого судді зі скаргою на рішення прокурора про відмову в задоволенні скарги на недотримання розумних строків прокурором у кримінальному провадженні. 16 липня 2018 р. процесуальним керівником В.Д. Кожелянко було задоволено його клопотання від 19 березня 2018 р. про проведення допиту. Упродовж 14 місяців погоджена прокурором слідча дія, його допит у режимі відеоконференції, так і не була проведена. Слідчим, прокурором порушені розумні строки проведення слідчої дії - його допиту в режимі відеоконференції. 24 грудня 2019 р. він звернувся в порядку ст. 308 КПК України до вищого прокурора зі скаргою на недотримання прокурором розумних строків досудового розслідування. 10 січня 2020 р. на його адресу надійшов лист за підписом заступника прокурора Чернівецької області А. Брюховича, в якому останній фактично відмовив у задоволенні скарги та не надав прокурору обов'язкових для виконання вказівок. Отже, вищий прокурор зобов'язаний був перевірити викладені у скарзі обставини, надати оцінку розумності строків виконання погодженої прокурором слідчої дії, яка упродовж півтора року так і не була виконана, й у разі порушення розумних строків надати вказівки щодо строків вчинення погодженої прокурором слідчої дії [6].

Також вагому частку у масиві оскаржуваних дій і рішень слідчих поліції та прокурорів як їхніх процесуальних керівників становлять оскарження постанов про закриття кримінального провадження. Слід відзначити, що вирішення таких скарг по суті загалом спрямовується за різними варіантами, серед яких найпоширенішими є: 1) прокурор самостійно скасовує постанову про закриття кримінального провадження та надає докази такого скасування до матеріалів справи, внаслідок чого суд виносить ухвалу про закриття провадження (ухвала Приморського районного суду м. Одеси від 06 травня 2020 р. у справі № 522/5340/20); 2) суд скасовує оскаржувану постанову про закриття кримінального провадження. Прикладом може слугувати ухвала Суворовського районного суду м. Одеси від 03 березня 2020 р. у справі № 523/2348/20, за якою судом встановлено, що предметом оскарження є постанова слідчого про закриття кримінального провадження від 19 вересня 2016 р., про яку стало відомо 07 лютого 2020 р. та яка, на думку особи, котра подала скаргу, є передчасною, незаконною та такою, що не відповідає завданням кримінального провадження. Зі скарги та доданих до неї матеріалів вбачається, що в ході досудового розслідування не було проведено ряд слідчих дій по кримінальному провадженню, після чого слідчим винесено постанову про закриття кримінального провадження. Також слідчим тривалий час не було повідомлено, на якій стадії перебуває кримінальне провадження. Крім того, ані слідчий, ані процесуальний керівник не повідомляли про закриття кримінального провадження. Суд зазначає, що вказані обставини в сукупності дають обгрунтовані підстави вважати, що досудове розслідування у кримінальному провадженні проведено без всебічного, повного й об’єктивного дослідження всіх обставин справи й оцінки слідчим всіх зібраних і перевірених доказів, тому висновок слідчого про закриття кримінального провадження є передчасним, а постанова про закриття кримінального провадження підлягає скасуванню [7].

Висновки. Підсумовуючи наведене вище, зауважуємо, що на практиці здійснення прокурорського нагляду за законністю діяльності поліції не завжди слугує ефективним інструментом забезпечення дотримання поліцією норм чинного законодавства. Саме тому важливим для функціонування системи стримувань і противаг є також 
судовий контроль за діяльністю як поліції, так і прокуратури. Виокремлюючи особливості прокурорського нагляду за дотриманням законності та дисципліни в діяльності Національної поліції України, зауважуємо, що це:

1) зовнішня форма забезпечення законності діяльності поліції - тобто така, яка здійснюється незалежним від структури Національної поліції України суб'єктом;

2) правова форма забезпечення законності діяльності поліції - усі заходи, дії, акти, рішення, що здійснюються та приймаються прокурором у рамках реалізації нагляду, вчиняються в межах чинного законодавства;

3) системна й активна, врегульована чинним законодавством діяльність, яка полягає у проведенні постійного спостереження, оцінки, аналізу законності оперативно-розшукових заходів, слідчих дій чи дій, спрямованих на дізнання, а також у ініціативних заходах - проведенні перевірок, надання доручень і вказівок, вжиття заходів щодо усунення порушень законності у ході проведення поліцією оперативно-розшукової діяльності, дізнання та досудового слідства. Прокурор, здійснюючи нагляд і погоджуючи відповідні клопотання, затверджуючи процесуальні рішення (а в окремих випадках приймаючи їх), зобов'язаний та уповноважений забезпечити об'єктивну, незалежну та кваліфіковану перевірку таких актів щодо їх відповідності чинному законодавству, спрямувати процесуальний рух справи у напрямі виконання завдань кримінального провадження;

4) об'єктом прокурорського нагляду є законність діяльності поліції, а не службова дисципліна. Також не вся діяльність поліції є об'єктом прокурорського нагляду, а лише та, яка здійснюється у ході провадження оперативно-розшукової діяльності, досудового слідства чи дізнання;

5) прокурорський нагляд здійснюється у формі процесуального керівництва, а це означає, що акти, які виносяться прокурором у разі виявлення порушень закону поліцейськими при здійсненні ними дізнання, досудового слідства чи оперативно-розшукової діяльності, приймаються виключно у процесуальній площині;

6) повноваження прокурора під час проведення ним нагляду за законністю діяльності поліції є більш широкими, аніж у керівника поліції при здійсненні внутрішньовідомчого нагляду у визначеній сфері (наприклад, затвердження обвинувального акта, звернення з ним до суду). Наведене окреслюе засоби для гарантування дотримання вимог чинного законодавства поліцейськими.

\section{Jimepamypa}

1. Трагнюк P.Р. Національна поліція як основний об'єкт прокурорського нагляду на сучасному етапі. Науковий вісник Міжнародного гуманітарного уні- верситету. Серія : Юриспруденція. 2017. Вип. 29 (2). C. $106-109$.

2. Звіт про роботу прокурора за січень-березень 2020 p. URL: https://old.gp.gov.ua/ua/stst2011. html?dir $\mathrm{id}=114137 \&$ libid $=100820 \& \mathrm{c}=$ edit\& $\mathrm{c}=$ fo\#.

3. Кримінальний процесуальний кодекс України : Кодекс України від 13 квітня 2012 р. № 4651-VI. Голос України. 2012. № 90-91.

4. Дворник А.А. Організація роботи прокуратури 3 нагляду за дотриманням законів у процесі досудового розслідування доведення до банкрутства : дис. ... канд. юрид. наук : 12.00.10. Київ, 2015. $199 \mathrm{c}$.

5. Фурсов Д.Ю. Співвідношення прокурорського нагляду, відомчого та судового контролю за законністю досудового розслідування кримінальних правопорушень проти безпеки дорожнього руху. Науковий вісник Міжнародного гуманітарного університету. Серія : Юриспруденція. 2019. № 41. Т. 2. С. 142-146.

6. Ухвала Шевченківського районного суду м. Чернівці від 21 січня 2020 р. у справі № 727/237/20. URL: http://www.reyestr.court.gov.ua/Review/87299522.

7. Ухвала Суворовського районного суду м. Одеси від 03 березня 2020 р. у справі № 523/2348/20. URL: http://www.reyestr.court.gov.ua/Review/88039177.

\section{Анотація}

Нетудихатка А. В. Особливості прокурорського нагляду за дотриманням законності та дисципліни в діяльності Національної поліції України. - Стаття.

Стаття присвячена розкриттю особливостей прокурорського нагляду за дотриманням законності та дисципліни в діяльності Національної поліції України. Для досягнення визначеної наукової мети автором з'ясовано міркування вчених із приводу сутності прокурорського нагляду за діяльністю поліції, його цілей i змісту. Проаналізовано статистичну інформацію, яка стосується досліджуваної проблематики. Також звернено увагу на окремі положення судової практики з розгляду скарг на дії прокурора як процесуального керівника, у зв'язку з чим виявлено певні проблеми здійснення прокурорського нагляду за дотриманням законності та дисципліни в діяльності поліції. На підставі дослідженого матеріалу виділено особливі характеристики прокурорського нагляду за дотриманням законності та дисципліни в діяльності Національної поліції України. Наголошено, що діяльністю поліції охоплено найбільшу кількість справ, у яких проводяться оперативно-розшукова діяльність, дізнання та досудове слідство. Наведені обставини зумовлюють необхідність у зазначених органів здійснювати постійну, системну та тісну співпрацю. Для ефективної реалізації визначених чинним законодавством завдань із нагляду за законністю діяльності поліції прокуратурі необхідно розробляти та втілювати в життя комплексні організаційно-правові заходи, спрямовані на виконання таких завдань, а також налагодження процесуальної, організаційної та інформаційної взаємодії з поліцією. Зроблено висновок, що прокурорський нагляд здійснюється у формі процесуального керівництва, а це означає, що акти, які виносяться прокурором у разі виявлення порушень закону поліцейськими при здійсненні ними дізнання, досудового слідства чи оперативно-розшукової діяльності, приймаються виключно у процесуальній площині. Повноваження прокурора під час проведення ним нагляду за законністю діяльності поліції є більш широкими, аніж у керівника поліції при здійсненні внутрішньовідомчого нагляду у визначеній сфері (наприклад, затвердження обвинувального акта, звернення з ним до суду). Наведене окреслює 
засоби для гарантування дотримання вимог чинного законодавства поліцейськими.

Ключові слова: прокурорський нагляд, Національна поліція, законність, дисципліна, процесуальний керівник, оперативно-розшукова діяльність, дізнання, досудове слідство.

\section{Summary}

Netudykhatka A. V. Peculiarities of prosecutorial supervision over observance of legality and discipline in the activity of the National Police of Ukraine. - Article.

The article is devoted to the disclosure of the peculiarities of the prosecutor's supervision over the observance of law and discipline in the activity of the National Police of Ukraine. To achieve a certain scientific goal, the author clarified the views of scientists on the essence of prosecutorial oversight of the police, its goals and content. Statistical information related to the researched problems is analyzed. Attention is also drawn to certain provisions of the case law on complaints about the actions of the prosecutor as a procedural manager, in connection with which certain problems of prosecutorial supervision over the observance of law and discipline in the police have been identified. On the basis of the researched material the special characteristics of prosecutorial supervision over observance of legality and discipline in activity of
National police of Ukraine are allocated. It is emphasized that the activity of the police covers the largest number of cases in which operative-search activities, inquiries and pre-trial investigation are carried out. These circumstances necessitate the need for these bodies to carry out constant, systematic and close cooperation. In order to effectively implement the tasks defined by the current legislation on the supervision of the legality of police activities, the prosecutor's office must develop and implement comprehensive organizational and legal measures aimed at performing such tasks, as well as establishing procedural, organizational and informational interaction with the police. It is concluded that prosecutorial supervision is carried out in the form of procedural guidance, which means that acts issued by the prosecutor in case of violations of the law by police during their inquiry, pre-trial investigation or operational search activities are taken only in procedural terms. The powers of the prosecutor during the supervision of the legality of police activities are broader than that of the police chief in the implementation of internal supervision in a particular area (for example, approval of an indictment, go to court with him). This creates important tools to ensure compliance with current legislation by police.

Key words: prosecutorial supervision, National police, legality, discipline, procedural manager, operative-search activity, inquiry, pre-trial investigation. 